\title{
Effect of Moisture Stress on Maize (Zea Mays L.) Yield and Water Productivity
}

\author{
Robel Admasu ${ }^{1 *}$, Abraham W Michael ${ }^{2}$ and Tilahun Hordofa ${ }^{3}$ \\ ${ }^{1}$ Irrigation Researcher, Jimma Agricultural Research Center, Ethiopia \\ ${ }^{2}$ Bio-System and Environmental Engineering, Hawassa University, Ethiopia \\ ${ }^{3}$ Senior Irrigation Researcher, Melkassa Agricultural Research Center, Ethiopia
}

Submission: December 19, 2018; Published: January 28, 2019

*Corresponding author: Robel Admasu, Irrigation Researcher, Jimma Agricultural Research Center, P.box 192, Jimma, Ethiopia

\begin{abstract}
Presently and in the future, irrigated agriculture faces water scarcity. Irrigation management will shift from emphasizing productivity per unit area to maximizing the production per unit of water consumed. Field experiment was carried out to determine the water use efficiency of maize under moisture stress condition and to identify the critical depth of application with limited effect on yield. The experiment was conducted at Awash Melkassa agricultural research center farm. The experiment was carried out in RCBD with three replications. Treatments include seven moisture stress levels and a control treatment (full irrigation, 85\% ETc, 75\% ETc, 65\% ETc, 55\% ETc, 45\% ETc, 35\% ETc and 25\% ETc). The different levels of irrigation had a highly significant ( $p>0.01)$ effect on maize grain yield, above ground biomass yield and harvest index. The highest grain yield was obtained from full irrigation $(5524.8 \mathrm{Kg} / \mathrm{ha})$ which was not significantly different with $85 \%$ ETc application ( $5206.5 \mathrm{Kg} / \mathrm{ha})$. In terms of water productivity, $25 \%$ ETc gives the highest water productivity and significantly different to all other treatments. In terms of yield, 85\% ETc application gave better water use efficiency and had no significant difference with all treatments except with 100 and 25\%ETc application. Hence, increased water saving, and associated water productivity can be achieved with the application of $85 \%$ ETc, without significant reduction on yield. In areas where water scarcity is high, 35 to $75 \%$ ETc application appears to be promising to depend on the availability of water resources with negligible trade-off in grain yield and water use efficiency.
\end{abstract}

Keywords: Moisture stress; ETc; Maize; Water productivity; Irrigation application

\section{Introduction}

Maize (Zea mays L.) is the world's third most important cereal crop after wheat and rice grown primarily for grain and secondly for fodder [1]. In Ethiopia, the crop is one of the leading food grains selected to assume a national commodity crop to support the food self-sufficiency program of the country. It is grown in moisture stress areas to high rainfall areas and from low lands to high lands [2]. Nevertheless, the production and productivity are strongly challenged by the rapidly dwindling water resources and the growing increase in competition for water.

Water scarcity is a global problem [3]. As cities grow and populations increase, the problem worsens since needs for water increase in households, industry and agriculture. Climate change has also contributed significantly to the water scarcity problem (WHO, 2009). Irrigation uses take almost $60 \%$ of all the world's freshwater withdrawals. It is therefore not surprising that irrigated agriculture, especially in arid and semi-arid areas, is facing pressures to reduce its water use in order to also cater for other water users.

In Ethiopia, irrigation development is increasingly implemented more than ever to supplement the rain-fed agriculture but due to the development of other water use sectors as well as increasing concerns for environment water has become increasingly a scarce resource. Among the different river basin found in Ethiopia, Awash River basin is one of the most utilized river basins for irrigated agriculture. Excessive water abstraction without properly assessing the available water resources in the basin contributes to water scarcity. This water shortage has motivated some researchers and farmers to find ways to produce crop with less irrigation water and changing from fully-irrigated to deficit irrigated cropping system.

Deficit irrigation has been widely investigated as a valuable and sustainable production strategy in arid and semi-arid regions. It is one of the ways of maximizing water use efficiency (WUE) for higher yields per unit of irrigation water applied (Kirda, 2002). Many studies have shown that there is a significant yield and yield component reduction occurs when maize produce under deficit irrigation. Maize is very sensitive to water stress [4,5]. Payero et al. (2008) reported that water stress can affect growth, development and physiological processes of maize plants, which reduce biomass yield. 
Different works have been done on maize moisture deficit based on decreasing the amount of irrigation water. However, much work has not been done to determine the critical depth water application where, the yield is not significantly affected. Therefore, considering the scarcity of irrigation water in the region, this research was aimed to determine the critical depth of water application and to evaluate the effect of deficit irrigation on water productivity of irrigated maize.

\section{Material and Methods}

\section{Description of experimental site}

The experiment was conducted at experimental farm of Melkassa Agricultural Research Center $\left(8^{\circ} 24^{\prime} \mathrm{N}\right.$ latitude and $39^{\circ} 35^{\prime} \mathrm{E}$ longitude at an altitude of 1,550 m.a.s.l. The site is situated in the upper Awash River Basin, the Central Rift Valley of the country. The long-term climate data of the area indicate is semi-arid and has an average annual rainfall is about $822.3 \mathrm{~mm}$, concentrated from December to April with irregular distribution. The textural class of the soil of the study area is clay loam with $163.3 \mathrm{~mm} / \mathrm{m}$ total available water. The climate water balance of the study area (Figure 1) shows that there is a need for irrigation water for almost the year round except for the months July to September.

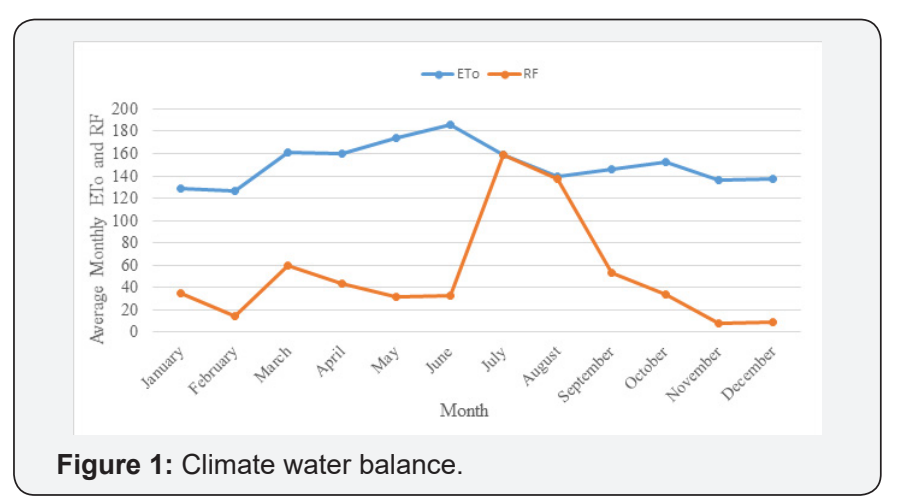

\section{Experimental design and treatment combination}

The experiment was conducted by using furrow irrigation methods and it includes seven moisture stress level viz., 85\% ETc, $75 \%$ ETc, 65\% ETc, 55\% ETc, 45\% ETc, 35\% ETc and 25\% ETc and a control irrigation of $100 \%$ ETc making a total of eight treatments. For control irrigation, irrigation water was applied to refill the soil to its field capacity based on allowable soil moisture depletion level of the crop. The rest treatments were taking the assigned percentage of the full irrigation water. The experiment was laid out in randomized complete block design (RCBD) with three replications resulting in a total of 24 plots. Melkassa II maize variety was used for this experiment, a crop that is commonly grown in dry areas under moisture stress condition also mostly grow in Melkassa with plant spacing of $75 \mathrm{~cm}$ between rows and $25 \mathrm{~cm}$ between plants.

\section{Procedure of the experimental study}

The source of irrigation water used for this experiment was brought from the Awash River. Water was carefully controlled to avoid the flow of water into water deficit plots. Before planting, the entire plot was uniformly pre-irrigated and light irrigations were applied prior to starting treatment applications for two weeks after planting, until the plants reached the established stage. A 3-inch standard Parshall flume used to measure irrigation water to be applied to individual plots. Water was allowed into the plot for the time calculated for its desire depth of application.

\section{Data collection}

yield and yield component parameters were recorded, and the treatments were compared based on above ground biomass yield, grain yield, yield response factor and harvest index. Also, water productivity was estimated.

Grain yield obtained from net harvested plot was adjusted to $12.5 \%$ moisture content and converted to hectare basis. Above ground biomass was determined by harvesting fifteen plants from the net plot area at physiological maturity and weighed after sun drying to a constant weight and converted to hectare basis. Harvest index was calculated as the ratio of grain yield to total above ground dry biomass yield multiplied by 100 . The yield response factor $\left(\mathrm{K}_{\mathrm{y}}\right)$ of maize which relates relative yield decrease to relative ET deficit under this study was estimated using the following equation [7]:

$$
1-\left(\frac{Y_{a}}{Y_{m}}\right)=K_{y}\left(1-\frac{E T_{a}}{E T_{m}}\right)
$$

Where: $\mathrm{Y}_{\mathrm{a}}=$ actual yield $(\mathrm{kg} / \mathrm{ha}), \mathrm{Y}_{\mathrm{m}}=$ maximum yield $(\mathrm{kg} /$ ha), $\mathrm{ET}_{\mathrm{a}}=$ actual evapotranspiration $(\mathrm{mm}), \mathrm{ET}_{\mathrm{m}}=$ maximum evapotranspiration $(\mathrm{mm})$, and $\mathrm{Ky}=$ yield response factor

The water productivity was calculated by the ratio of harvested yield per total water used (Zwart and Bastiaanssen, 2004).

$$
W P=\frac{Y}{E T}
$$

Where, WP is water productivity $\left(\mathrm{kg} / \mathrm{m}^{3}\right)$, Y crop yield (kg/ha) and ET is the seasonal crop water consumption by evapotranspiration $\left(\mathrm{m}^{3} / \mathrm{ha}\right)$.

\section{Data analysis}

The collected data were subject to statistical analysis appropriate to RCBD design. SAS software version 9.2 for windows was used for analysis [8]. Whenever the treatment effects were found significant, GLM test at 1 and 5\% was performed to assess significant difference among treatments means.

\section{Result and Discussion \\ Grain yield}

The grain yield in the experiment was proportional to the availability of water but as stress intensity increased grain yield decreased (Table 1). The analyzed result indicated that there is 
a highly significant $(\mathrm{P}<0.01)$ difference among moisture stress treatments on grain yield (Table 1). From table 1, the control treatment (i.e. 100\% ETc) gave the highest yield (5524.8 Kg ha${ }^{1}$ ) followed by moisture stress treatment of $85 \%$ ETc $(5206.5 \mathrm{Kg}$ ha $^{-1}$ ) which was not statistically different. The minimum grain yield was recorded from moisture stress treatment of $25 \%$ ETc (1468.6 Kg ha-1) and this was statistically inferior to all other treatments (Table 1). Decreasing applied water by 25, 35, 45, 55,65 and $75 \%$ of ETc led to decreased grain yield of corn by 12.2, 26.4, 36.1, 53.21, 61.8 and 73.4\%, respectively. These results are consistent with findings of Mansouri et al. [9], who showed that grain yield was affected by irrigation water amount. Different researches conducted on sorghum (Klocke et al., 2012) and wheat (Meskelu et al., 2013) revealed that, as the moisture stress level increased the production of the crop will declined, which agreed with the current finding. Also, Karasu et al. [10] stated that deficit irrigation applications from full irrigation to no irrigation decreased the grain yield by $60 \%$.

\section{Above ground dry biomass yield}

There is a highly significant $(\mathrm{P}<0.01)$ difference among moisture stress treatments on above ground biomass yield. The result in table 3 , showed that full irrigation has the highest biomass yield (12.1 $\mathrm{tha}^{-1}$ ) followed by moisture stress level of $85 \%$ crop water requirement $\left(11.7 \mathrm{t} \mathrm{ha}^{-1}\right)$ which was not statistically different. From the result, the minimum above ground biomass yield obtained from treatment received 25\% of its crop water requirements through the whole growing season (6.7t ha-1) and this was statistically inferior to all other treatments (Table 1). The above ground biomass production in the experiment was proportional to the availability of water i.e. as the stress intensity increased biomass production decreased.

From the current finding, water supply reduced from 100 to $25 \%$ ETc the above ground dry biomass yield decreased by $44.6 \%$. These findings agreed with the experimental results reported on maize by Pandey et al, [11]. Lower leaf production and dry matter is attributed to water stress [12]. Moser et al. [13], also reported that biomass was reduced by moisture stress.

The analysis of variance indicated that soil moisture stress had a highly significant $(\mathrm{p}<0.01)$ effect on harvest index of maize (Table 1). The highest harvest index of maize was recorded from control treatment (100\% ETc) and it had no significant difference with treatments received 85 and $75 \%$ of its crop water requirements for all growing periods, while the lowest harvest index was recorded from treatment received $25 \%$ of its crop water requirements for the whole growing seasons and had no significant difference with treatments received 35,45 , and $55 \%$ of its crop water requirement for the whole growing seasons. Increasing irrigation from $25 \%$ ETc to $100 \%$ ETc harvest index significantly increased and the increment was consistent. This result implied that, grain formation was highly and strongly affected by moisture content (Table 1 ).

Table 1: Effect of moisture stress on maize grain yield, biomass yield and harvest index.

\begin{tabular}{|c|c|c|c|}
\hline Treatments & Grain Yield (Kg ha $\left.{ }^{-1}\right)$ & Above Ground Dry Biomass Yield (t ha $\left.{ }^{-1}\right)$ & Harvest Index \\
\hline $100 \%$ ETc & $5524.8^{\mathrm{a}}$ & $12.1^{\mathrm{a}}$ & $0.46^{\mathrm{a}}$ \\
\hline $85 \%$ ETc & $5206.5^{\mathrm{a}}$ & $11.7^{\mathrm{a}}$ & $0.44^{\mathrm{ab}}$ \\
\hline $75 \%$ ETc & $4851.0^{\mathrm{b}}$ & $10.9^{\mathrm{b}}$ & $0.44^{\mathrm{ab}}$ \\
\hline $65 \%$ ETc & $4064.1^{\mathrm{c}}$ & $10.8^{\mathrm{b}}$ & $0.38^{\mathrm{b}}$ \\
\hline $55 \%$ ETc & $3528.6^{\mathrm{d}}$ & $10.1^{\mathrm{c}}$ & $0.35^{\mathrm{bc}}$ \\
\hline $45 \%$ ETc & $2585.0^{\mathrm{e}}$ & $9.2^{\mathrm{d}}$ & $0.28^{\mathrm{c}}$ \\
\hline $35 \%$ ETc & $2108.1^{\mathrm{f}}$ & $8.9^{\mathrm{d}}$ & $0.24^{\mathrm{cd}}$ \\
\hline $25 \%$ ETc & $1468.6^{\mathrm{g}}$ & $6.7^{\mathrm{e}}$ & $0.22^{\text {cd }}$ \\
\hline LSD $(0.01)$ & 335.9 & 0.5 & 0.07 \\
\hline CV & 5.2 & 4.7 & 6.2 \\
\hline
\end{tabular}

*Means followed by the same letters in a column are not significantly different from each other at a $1 \%$ probability level.

\section{Water productivity}

Analysis of variance revealed that moisture stress levels were significant in affecting water use efficiency on grain yield production of maize (Table 2). The highest water productivity was obtained from treatment of $25 \%$ ETc followed by $35 \%$ and $85 \%$ ETc while, the lowest water productivity was obtained from the control treatment (i.e. $100 \%$ ETc). From the result, water use efficiency decreased with increasing water supply and reduction of yield. Previous studies indicated that water productivity ranged from 0.41 to $2.71 \mathrm{~kg} \mathrm{~m}^{3}$ [14-16] which agrees with these finding.
Table 2: Effect of moisture stress on water productivity.

\begin{tabular}{|c|c|}
\hline Treatments & Water productivity $\left(\mathbf{k g} / \mathbf{m}^{3}\right)$ \\
\hline $100 \%$ ETc & $0.67^{\mathrm{c}}$ \\
\hline $85 \%$ ETc & $0.78^{\mathrm{b}}$ \\
\hline $75 \%$ ETc & $0.78^{\mathrm{b}}$ \\
\hline $65 \%$ ETc & $0.75^{\mathrm{bc}}$ \\
\hline $55 \%$ ETc & $0.77^{\mathrm{b}}$ \\
\hline $45 \%$ ETc & $0.75^{\mathrm{b}}$ \\
\hline $35 \%$ ETc & $0.81^{\mathrm{b}}$ \\
\hline
\end{tabular}




\begin{tabular}{|c|c|}
\hline $25 \%$ ETc & $0.98^{\mathrm{a}}$ \\
\hline LSD $(0.05)$ & 0.07 \\
\hline CV & 7.82 \\
\hline
\end{tabular}

*Means followed by the same letters in a column are not significantly different from each other at a $5 \%$ probability level.

\section{Yield response factor $\left(\mathrm{K}_{\mathrm{y}}\right)$}

The magnitude of $\mathrm{K}_{\mathrm{y}}$ value indicates the sensitivity of the irrigation protocol for water stress and subsequent yield decrease. Results of the analysis of yield and water, as indicated in Table 3, showed that the highest $\mathrm{K}_{\mathrm{y}}$ was 0.98 and 0.97 attained at $25 \%$ ETc and $45 \%$ ETc respectively. The higher $\mathrm{K}_{\mathrm{y}}$ values of 0.98 and 0.97 could be an indication of severe water stresses. This implies that the rate of relative yield decrease resulting from water stress is proportionally the same to the relative evapotranspiration deficit. The lowest yield response factor 0.38 was observed at $85 \%$ ETc and it indicated that the water deficit level does not have a significant impact on maize grain yield when compared with optimum irrigation. According to Kirda et al. [17], the $\mathrm{K}_{\mathrm{y}}$ value for field crops goes from 0.2 to 1.15 which agrees with the reported result [18-33].

Table 3: Yield response factor values for moisture stress treatments.

\begin{tabular}{|c|c|c|c|c|c|c|c|}
\hline Treatment & $\mathrm{Y}_{\mathrm{a}}(\mathrm{Kg} / \mathrm{ha})$ & $\mathrm{ET}_{\mathrm{a}}(\mathrm{mm})$ & $\mathrm{ET}_{\mathrm{m}}(\mathrm{mm})$ & $\mathbf{Y}_{\mathrm{m}}(\mathrm{Kg} / \mathrm{ha})$ & $1-\left(\frac{Y_{a}}{Y_{m}}\right)$ & $1-\left(\frac{E T_{a}}{E T_{m}}\right)$ & $\mathbf{K}_{\mathbf{y}}$ \\
\hline $100 \%$ ETc & 5524.8 & 760.3 & 760.3 & 5524.8 & 0 & 0 & - \\
\hline $85 \%$ ETc & 5206.5 & 646.2 & 760.3 & 5524.8 & 0.06 & 0.15 & 0.38 \\
\hline $75 \%$ ETc & 4851 & 570.2 & 760.3 & 5524.8 & 0.12 & 0.25 & 0.49 \\
\hline $65 \%$ ETc & 4064.1 & 494.2 & 760.3 & 5524.8 & 0.26 & 0.35 & 0.76 \\
\hline $55 \%$ ETc & 3528.6 & 418.2 & 760.3 & 5524.8 & 0.36 & 0.45 & 0.8 \\
\hline $45 \%$ ETc & 2584.9 & 342.1 & 760.3 & 5524.8 & 0.53 & 0.55 & 0.97 \\
\hline $35 \%$ ETc & 2108.1 & 266.1 & 760.3 & 5524.8 & 0.62 & 0.65 & 0.95 \\
\hline $25 \%$ ETc & 1468.6 & 190.1 & 760.3 & 5524.8 & 0.73 & 0.75 & 0.98 \\
\hline
\end{tabular}

Where $\mathrm{Y}_{\mathrm{a}}$ - actual grain yield, $\mathrm{Y}_{\mathrm{m}}$ - maximum grain yield, $\mathrm{ET}_{\mathrm{m}}-$ maximum evapotranspiration, $\mathrm{ET}_{\mathrm{a}}-$ actual evapotranspiration and $\mathrm{K}_{\mathrm{y}}-$ yield response factor.

\section{Conclusion}

A study was conducted to determine the effect of moisture stress on maize yield, yield components and water use efficiency. Data on plant height, thousand seed weight, number of kernels per ear, grain weight per cob, grain yield, biomass yield, harvest index and yield response factor were used to compare the difference in crop yield and yield components. In addition, the water productivity associated with irrigation treatments were also evaluated by water productivity.

The study result indicated that there is no significant difference among full irrigation and 85\% ETc on average grain yield and above ground biomass yield. The maximum grain yield and above ground biomass yield was obtained from full irrigation followed by $85 \%$ ETc. whereas the minimum was obtained from $25 \%$ and $35 \%$ ETc. Also, Water use efficiency was significantly influenced by variation in the level of irrigation water. $25 \%$ ETc gives the highest WUE followed by 35\% ETc and 85\% ETc. Therefore, it could be concluded that the critical depth of water application for moisture stress area should not be below $85 \%$ of full maize water requirement for obtaining relatively good grain yield with a better improvement on water productivity.

\section{References}

1. Nelson RL (2005) Tassel emergence and pollen shed. Corny news network.
2. Mengesha K, Gashaw B, Birhanu T, Malesse W, Yirga D, et al. (1993) Maize production trends and research in Ethiopia. In: Tolessa B, Ransom JK (Eds.), Proceedings of the First National Maize Workshop of Ethiopia. IAR/ CIMMYT, Addis Ababa, Ethiopia, pp. 4-12.

3. Fereres E, Soriano MA (2007) Deficit irrigation for reducing agricultural water use. Special issue on 'Integrated approaches to sustain and improve plant production under drought stress'. J Exp Bot 58(2): 147-159.

4. Pandey RK, Maranville JW, Admou A (2000) Deficit irrigation and nitrogen effects on maize in aSahelian environment I. Grain yield and yield components. Agric Water Management 46(1): 1-13.

5. Cakir R (2004) Effect of water stress at different development stages on vegetative and reproductive growth of corn. Field Crops Research 89(1): 1-16.

6. Payero JO, Tarkalson DD, Irmak S, Davison D, Petersen JL (2008) Effect of irrigation amounts applied with subsurface drip irrigation on corn evapotranspiration, yield, water use efficiency, and dry matter production in a semiarid climate. Agric Water Manage 95: 895-908.

7. Doorenbos J, Kassam AK (1979) Yield response to water. Irrigation and Drainage Paper 33, FAO, Rome, Italy.

8. SAS Institute (1996) SAS Users'guide. Version 6 SAS Institute Cary, NC.

9. Mansouri-Far CSA, Sanavy MM, Saberali SF (2010) Maize yield response to deficit irrigation during low sensitive growth stages and nitrogen rate under semi-arid climatic conditions. Agricultural Water Management 97(1): 12-22.

10. Karasu A, Kuscu H, OZ M, Bayram G (2015) The Effect of Different Irrigation Water Levels on Grain Yield, Yield Components and Some 
Quality Parameters of Silage Maize in Marmara Region of Turkey. Not Bot Horti Agrobo 43(1):138-145

11. Pandey RK, Herrera WAT, Villegas AN, Pendleton JW (1983b) Drought response of grain legumes under irrigation gradient: II. Plant water status and canopy temperature. Agronomy Journal 76(4): 553-557.

12. EI-Bagoury OH, Shaheen AM (1977) Germination and Seedling characteristics response of five crop species to water deficit. Seed science and technology 5(3): 527-537.

13. Moser SB, Feil B, Jampatong S, Stamp P (2006) Effect of pre-anthesis drought nitrogen fertilizer rate and variety on grain yield, yield components and harvest index of tropical maize. Agric Water Manage 81(1-2): 41-58.

14. Kar G, Verma HN (2005) Phenology based irrigation scheduling and determination of crop coefficient of winter maize in rice fallow of eastern India. Agric Water Manage 75(3): 169-183.

15. Dagdelen N, Yilmaz E, Sezgin F, Gurbuz T (2006) Water-yield relation and water use efficiency of cotton (Gossypium Hirsutum L.) and second crop corn (Zea mays L.) in western Turkey. Agric Water Manage 82 (12): $63-85$

16. Mengü GP, Ozgürel M (2008) An evaluation water-yield relations in maize (Zea mays L.) in Turkey. Pak J Biol Sci 11(4): 517-524.

17. Kirda C, Kanber R (1999) Water, no longer a plentiful resource, should be used sparingly in irrigated agriculture. In: Kirda C, Moutonnet P, Hera C, Nielsen DR (Eds.), Crop yield response to deficit irrigation, Dordrecht, The Netherlands, Kluwer Academic Publishers, Netherlands.

18. Bajwa MS, Khtar AA, Hussam MR, Raja MB (1987) Effect of irrigation requirement and nitrogen rates on the yield and protein contents of maize. Pak J Agri Res 8: 325-329.

19. Bozkurt Y, Yazar A, Gencel B, Sezen MS (2006) Optimum lateral spacing for drip-irrigated corn in the Mediterranean Region of Turkey. Agricultural Water Management 85(1-2): 113-120.

20. Eck HV (1984) Irrigated corn yield response to nitrogen and water. Agron J 76(3): 421-428.

21. Eck HV (1985) Effect of water deficit on yield, yield components and water use efficiency of irrigated corn. Agron J 78(6): 1035-1040.
22. FAO (Food and Agricultural Organization) (1979) Yield response to water. In: Doorenbos J, Kassam AH (Eds.), Irrigation and Drainage Paper No. 33, FAO, Rome.

23. Fischer KS, Palmer FE (1984) Tropical Maize. In: Goldsworthy PR, Fischer NM (Eds.), The Physiology of Tropical Field Crops. Wiley, New York, pp. 213-248.

24. Grant RF, Jackson BS, Kiniry JR, Arkin GF (1989) Water deficit timing effects on yield components in maize. Agron J 81(1): 61-65.

25. Harder D, Carlson RE, Shaw RH (1982) Yield, yield components and nutrient content of corn grain as influenced by post-silking moisture stress. Agron J 74(20029: 275-278.

26. Hesamoddin M, Ali S, Majid S (2012) Evaluation of Drought Stress Effects on Yield Components and Seed Yield of Three Maize Cultivars (Zea mays L.) in Isfahan region. Intl J Agri Crop Sci 4(19): 1436-1439

27. Hirich A, Rami A, Laajaj K, Choukr-Allah R, Jacobsen SE, et al. (2012) Sweet Corn Water Productivity under Several Deficit Irrigation Regimes Applied during Vegetative Growth Stage using Treated Wastewater as Water Irrigation Source. World Academy of Science, Engineering and Technology 61: 840-847

28. Jacobs BC, Pearson CJ (1991) Potential yield of maize determined by rate of growth and development of ears. Field Crops Res 27(3): 281298.

29. Karam F, Breidy J, Stephan C, Rouphael J (2003) Evapotranspiration, yield and water use efficiency ofdrip irrigated corn in the Bekaa Valley of Lebanon. Agric.Water Management 63(2): 125-137.

30. Kirtok Y (1998) Corn production and use. Kocaoluk Press, Istanbul, Turkey, pp. 445.

31. Ogretir K (1993) The water-yield relationships of corn in Eskisehir conditions. PhD thesis, Irrigation and Agricultural Structures, Graduate School of Natural and Applied Sciences. Cukurova University, Adana.

32. Sammis TW, Smeal D, Williams S (1988) Predicting corn yield under limited irrigation using plant height. Transactions of the ASAE (Amer. Soc. Agric. Engineers) 3(13): 830-838.

33. Stone PJ, Wilson DR, Reid JB, Gillespie RN (2001) Water deficit effects on sweet corn. Water use, radiation use efficiency growth and yield. Aust J Agr Res 52(1): 103-113.

Your next submission with Juniper Publishers
will reach you the below assets
- Quality Editorial service
- Swift Peer Review
- Reprints availability
- E-prints Service
- Manuscript Podcast for convenient understanding
- Global attainment for your research
- Manuscript accessibility in different formats
( Pdf, E-pub, Full Text, Audio)
- Unceasing customer service
Track the below URL for one-step submission
https://juniperpublishers.com/online-submission.php

